XV. Some Observations on the White Horse of Berkshire; by WILliam J. Тномs, Esq. F.S.A. in a Letter addressed to Тномаs Амуот, Esq. Treasurer of the Society.

Read 6th March 1845.

My DeAR Sir,

THE remarkable Monument of antiquity which gives its name to the Vale of White Horse in Berkshire, has not, I believe, attracted the particular attention of any antiquary since 1738, when the Rev. Francis Wise published his "Letter to Dr. Mead, concerning some Antiquities in Berkshire," \&c.; or, perhaps I should rather say, since 1742, the date of his second work upon the subject, entitled "Further Observations upon the White Horse and other Antiquities in Berkshire," \&c.

Under these circumstances, and as the perusal of Mr. Wise's original and very interesting pamphlets has created some doubts in my mind as to the accuracy of his views with regard to the origin of this remarkable figure, I beg to submit to you, and to the consideration of the Society of Antiquaries, some. observations upon the subject, not in the presumption that they will establish the object which this curious monument is intended to commemorate, but rather as a small collection of materials which may prove useful to future inquirers into its history.

From the silence of Leland, and the slight mention which Camden (who only notices it incidentally) has made of the White Horse, many have been inclined to doubt whether the figure possesses any claim to great antiquity. These doubts are, however, totally groundless. 
Wise has proved that the "Vale of White Horse" was known by that name in the 42nd of Edward the Third (1368-9), by a reference to an entry upon the Close Rolls for that year, in which it is recorded, that "Gerard de l' Isle tient en la Vale de White Horse 1 fee;" and, by the kindness of Sir Henry Ellis, I am now enabled to adduce evidence that the White Horse was in existence so early as the reign of Henry the Second. The proof is contained in two valuable cartularies of the abbey of Abingdon, now preserved in the British Museum. In one of these is the following entry relating to Sparsholt :

"Prope Montem, ubi ad album equum scanditur, ab antiquo tempore Ecclesia ista manerium Offentun appellatum in dominio possidet, juxta quod Villa $x$. hidarum adjacet ex jure ecclesie quam Speresholt nominavit. Hunc miles, Anskillus nomine, de ecclesia tempore Rainaldi abbatis, pro unius militis servitio tenebat. Verum hunc contigit et ipsius abbatis regisque junioris Willelmi inimicitias adeo incurrisse postea, ut in regia poneretur captione ibique moriretur." a

This carries back the known and acknowledged existence of the White Horse to the reign of Richard the First, for such is the date of the volume from which it is extracted; while by the other cartulary, which was written in the reign of Henry II., in 1171 or soon after, it is ascertained that the hill on which it is figured bore the name of White Horse Hill at a yet earlier period. The following is the passage in question:

"Consuetudinis apud Anglos tunc erat, ut Monachi qui vellent pecuniarum patrimoniorumque forent susceptibiles, ipsisque fruentes quomodo placeret dispensarent. Unde et in Abbendonia duo, Leofricus et Godricus Cild appellati, quorum unus, Godricus, Spersholt juxta locum qui vulgo Mons Albi Equi nuncupatur, alter Leofricus Hwitceorce super flumen Tamisie maneria sita patrimoniali jure obtinebant. Quorum unum, id est Spersholt, usque hodie ecclesie feudo remansit, aliud vero Wigodus oppidanorum Walingafordensium dominus possedit, velle Monachorum predictorum hinc et inde de eisdem terris sic se referente. Hec accidisset de una secus quam de altera,

- Cottonian MS. Claud. B. vi. fol. 151. 
si viro secundum morem gentis necdum austeriora edocto ferre remissius blandiretur; domno Adelelmo abbate dominatum loci hujus. obtinente. $b$

Aldelm was abbot of Abingdon from 1072 to 1084 .

In the face of such historical testimony to the existence of this remarkable monument soon after the Norman Conquest, there can be little hesitation in pronouncing it the production of a far earlier period.

Mr. Wise is of opinion, and he maintains that opinion with considerable learning and ingenuity, that the White Horse is a monument of the West Saxons, made in memory of a great victory obtained by Alfred over the Danes in 871 ; while the object of the present communication is to show the probability that it is commemorative of the ancient. religion of the country. Nor can this opinion be considered very unreasonable, when it is remembered that the worship of the Horse was common to the Celtic and Germanic, ${ }^{c}$ as well as the Sclavonic tribes.

The work may consequently be even of British origin ; and, when we consider the resemblance which the figure of the Horse bears to that which is exhibited on some of the coins now admitted by our best numismatists to be the coinage of the ancient Britons, it will scarcely be matter of surprise should this remarkable monument find antiquaries disposed to contend for its Celtic origin. That it may be so, and as such commemorative of the mythic Horse of the Britons, is certainly possible; but the far greater probability is that it refers to the "Sacred Horses," which form so important an object in the mythological system of our Saxon forefathers, and other people of the Germanic race.

From these sacred horses it is probable that many of the ancient heroes derived their names ; of which Hengist and Horsa furnish a striking example, those names being nearly synonymous; although the former, Hengist

b Cottonian MS. Claud. C. Ix. fol. 132.

c See Grimm Deutsche Mythologie, p. 626, ed. 1844. "Mir scheint der pferdecultus überhaupt auf gleiche weise Celten Deutschen und Slaven eigen, welche einzelnen stämme unter diesen volkern ihm zumeist ergeben waren, wird sich kunftigen forschungen allmälich enthüllen."

voL. XXXI. 
or Hengst, is, in the German and some other of the Teutonic tongues, more particularly applied to stallions.

The important position which the Horses of the gods assume in the mythological poems of the North, is a point too which on the present occasion cannot be passed over in silence. Sleipnir, the eight-footed horse of Odin, is of these the most important; and it is a very remarkable fact, in connexion with the present inquiry, as showing for how long a time after the introduction of Christianity the memory of this mythic steed was preserved in the popular customs and observances of the people, that, until a comparatively recent period, at least as lately as the sixteenth century, it was a custom in Mecklenburgh, at the conclusion of harvest, to leave in the fields some small portion of the earth's produce as an offering to Woden, and as fodder for his horse; the reapers shouting at the conclusion of their labours -

"Woden, bring your horse now fodder,

Now thistle and thorn,

Another year, better corn!" d

I think I have met with an allusion to a similar custom in this country, although I cannot now refer to it.

The truth of that striking and often quoted passage from the De Moribus Germanorum of Tacitus, ${ }^{e}$ which Mr. Wise has already adduced, to show that the Germans consecrated woods and groves, and were accustomed to regard the warnings and auguries of Horses, for which purpose White Horses were

d Grimm, Deutsche Mythologie, s. 141.

"Wode, hale dinem rosse nu voder,

Nu distel unde dorn,

Tom audern jar beter korn."

e After saying " lucos et nemora consecrant," Tacitus proceeds, "proprium gentis, equorum quoque prasagia ac monitus experiri. Publice aluntur, iisdem nemoribus ac lucis, candidi et nullo mortali opere contacti, quos pressos sacro curru sacerdos ac rex vel princeps civitatis comitantur, hinnitusque ac fremitus observant. Nec ulli auspicio major fides non solum apud plebem sed apud proceres, apud sacerdotes : se enim ministros deorum, illos conscios putant." 
kept in such hallowed groves, and never desecrated by being put to any kind of labour, receives abundant confirmation from later writers.

One of the most remarkable instances is quoted by Grimm in his Deutsche Mythologie, ${ }^{\mathbf{f}}$ from one of the Northern Saga, the Saga of Olaf Trygvesson. Grimm quotes from the rare edition of 1689-90, and notices, with regret, that the chapter, from which his quotation is taken, is omitted in some of the later editions of the work. The account is as follows :

"Olaf having been informed that the inhabitants of Drontheim had relapsed into the worship of Freyr, he commanded them to destroy the statue of Freyr which was still remaining among them. This they refused to do. Whereupon Olaf summoned an assembly of them; and having determined that he himself would destroy the idol, sailed to that part of the coast where stood the temple of Freyr. When he landed he found the Sacred Horses of the god depasturing in its precincts. The king instantly mounted the stallion, and permitting his courtiers to take the mares, they thus rode to the temple. On arriving there Olaf overthrew the idols, and took away with him the statue of Freyr.

"When the people found how their gods had been put to shame, and how the image of Freyr had been removed, they well knew that it was the act of the king, and attended the meeting to which he had summoned them. The king having placed Freyr's image in the midst of the assembled people, demanded of them, 'Know ye this man?' They answered: 'It is Freyr, our god.' 'How has he proved his power to you?' inquired Olaf: 'He has ofttimes spoken with us, prophesied unto us coming events, and bestowed upon us peace and plenty.' ' It was the devil who spake with you,' said the king, and taking up an axe, he called out to the idol, 'Now help yourself, defend yourself, if you can.' But Freyr remaining silent, Olaf smote off both his hands, and then preached to the people, and exhorted them to renounce their idolatry."

This story bears in many points so remarkable a resemblance to the narrative which Beda has left us of the profanation of the heathen temple

f Deutsche Mythologie, s. 622 . 
at Godmundham, in Yorkshire, by Coiffi the high priest, when Edwin and his chief friends and counsellors were converted to Christianity by the preaching of Paulinus, that it is scarcely too much to believe, that we have recorded, in these two instances, the form of procedure, adopted in all cases, for the desecration of the temples of heathenism.

I quote Beda's narrative from the English version, edited by Dr. Giles, and can hardly help suspecting that the Stallion on which Coiffi rode was one of the Sacred Horses attached to the temple ; and not one of the king's, as Beda relates. Coiffi is described as having, after hearing Paulinus, advised the king "to set fire to the temples and altars, which we have consecrated without reaping any benefit from them." In short, the king publicly gave his license to Paulinus to preach the Gospel, and renouncing idolatry, declared that he received the faith of Christ; and when he inquired of the high priest, who should first profane the altars and temples of their idols with the enclosures that were about them? he answered: "I, for who can more properly than myself destroy those things, which I worshipped through ignorance; for an example to all others, through the wisdom which has been given me by the true God!" Then, immediately, in contempt of his former superstitions, he desired the king to furnish him with arms and a stallion; and mounting the same, he set out to destroy the idols; for it was not lawful before for the high priest either to carry arms or to ride on any but a mare. Having, therefore, girt a sword about him with a spear in his hand, he mounted the king's stallion and proceeded to the idols. The multitude beholding it concluded he was distracted; but he lost no time, for as soon as he drew near the temple he profaned the same, casting into it the spear which he held; and rejoicing in the know-

g The Ecclesiastical History of the English Nation, translated from the Latin of Bede, \&c. by J. A. Giles, LL.D. 8vo. 1840, pp. 110, 111.

The reader desirous of consulting the original, is referred to pp.136-7, of Venerabilis Beda Historia Ecclesiastica Gentis Anglorum, ad fidem Codicum Manuscriptorum recensuit Josephus Stevenson, 8vo. 1838. - The first of the admirable series of our national Chronicles, published by the British Historical Society. 
ledge of the worship of the true God, he commanded his companions to destroy the temple, with all its enclosures, by fire."

But to proceed : It may be said, first, that, admitting that the Saxons were accustomed to keep such sacred horses within the groves by which their temples were surrounded, what proof have we, that any Saxon Temple stood in the neighbourhood of the remarkable figure now under consideration ? And, secondly, even though the existence of such temple be established, what connexion can there have been between it, and the figure in question?

To the first I answer, that the extensive Downs on which this extraordinary monument is found, were formerly remarkable for the groves of ash trees with which they were covered; and the memory of which is preserved in the name of the parish of Ashbury, (which, as Wise has already proved, was formerly called Ashdown,) and in those of other localities in the neighbourhood.

Wise, when speaking on this point, observes: "Near Letcombe is a shrubby place still called The Ashes, and Letcombe Ashes; where, as I have been informed by a curious and learned gentleman of this neighbourhood, grew, within the memory of several persons lately dead, abundance of tall and very fine ashes."

Now the ash, it must be remembered, was reckoned by the Saxons among the sacred trees, being regarded by them with a veneration almost, if not altogether, equal to that which they paid to the oak. Nor is this to be wondered at, when we bear in mind that in the Edda, the Voluspa, and many other of those literary remains of the North to which we are indebted for all we know of the mythological system of our ancestors, the Ash tree, Yggdrassil, , is repeatedly spoken of as " the most sacred tree of the gods : "the tree under which the gods sate in judgment;" as "the tree from which the first man was formed."

h Ask veit-ék standa, heitir Ygg-prasill

Hár-bapmr, ausinn hvitom auri ;

pápan kóma dauggvar, pærs i dali falla.

Vaulu-Spa, edit. Ettmuller, s. $\mathbf{9}$.

See Schrader, Germanisehe Mythologie, s. 88 and 172. 
It is clear, then, that the Ash was reverenced by our Saxon forefathers : and when Plot, in his History of Staffordshire, tells us, " the common people believe that it is very dangerous to break a bough from the Ash, to this very day," he proves that this feeling of veneration was not then extinguished among us.

Taking, therefore, these various circumstances into consideration, I am inclined to believe that the White Horse of Berkshire is no monument commemorative of victory; but a memorial formed by the Saxons, at the time of their conversion to Christianity, of the Sacred White Horse, which in the days of Paganism had depastured in the sacred grove of Ashes, and I am confirmed in this opinion by the recollection that this monument is not a solitary one, but that several others of similar character are still existing in the country. $i$ These, however, with your permission, shall form the subject of a separate communication.

\section{Believe me,}

My dear sir,

Your very faithful and obedient servant,

WILLIAM J. THOMS.

Since writing the above, I have been favoured by my friend Mr. Akerman with the subjoined Letter, in which (confirming my anticipation) he expresses his belief that the White Horse is of Celtic origin.-He has accompanied it with a sketch of the present appearance of the Horse at Uffington.

i I may mention among other monuments of this description still existing, hitherto but comparatively unnoticed, and to which my attention has been directed since the present communication was commenced, one near Ripon in Yorkshire, and one not far from Fraserburgh in Scotland. 
My dear Sir,

Lewisham, 15 February 1845.

I FEAR I can tell you nothing about the "White Horse" of the Wiltshire and Berkshire Downs in addition to what has already been published; but I am enabled to forward you a very accurate drawing of that at Uffington, in the latter county, presented to me some years ago by Mr. Christopher Edmonds, by whom the dimensions were taken.

I am not disposed to subseribe to the popular tradition, that these figures are of Saxon origin. We all know that the horse was a favourite Saxon and Anglo-Saxon badge, and, indeed, their national symbol; but it is equally certain that it was also a favourite one with the Celtic tribes. It is a constantly occurring type of the Gaulish and British coins, which, though modelled on those of civilised states, appear to be accommodated to the tastes and feelings of the people who adopted them. Although thus modelled and accommodated, the religious motive of the type appears to me to be no less obvious. It would therefore seem highly probable that while Caligula was contemplating the raising his horse to the consulship, the Britons, Gauls, and Germans were paying divine honours to this noble animal.

The Marquis de Lagoy, a very sound and able antiquary, has published a coin of the Belindi, a people of Aquitaine, mentioned by Pliny, ${ }^{h}$ on the Reverse of which is a horse, not galloping, as usually represented on the Gaulish and British money, but standing within a distyle temple. The learned Marquis supposes that this figure represents the goddess Epona, mentioned by Apuleius, ${ }^{i}$ and, if the conjecture be not allowed, it cannot be doubted that the Gauls worshipped some divinity under that form; a fact of which the coin in question is the sole but authentic evidence.

The figure of the White Horse at Uffington appears to be one of the rudest of its kind, and so strongly resembles those on the more barbarous British coins, that I do not hesitate to class it with the same period. The disjointed limbs, the outré character of the drawing of the head, and, in fact, the whole details, remind one of almost equally barbarous attempts on the primitive money of our ancestors.

$$
\text { h Lib. iv. c. } 19 . \quad \text { i Metam. lib. iii. }
$$


I am glad the subject is in your hands, and hope you will be enabled to throw some light on these remains; but, if my conjecture as to their origin be well founded, I fear your search for data will be fruitless, for even- the names on several British coins are yet unexplained, and we look in vain in Cæsar and Tacitus for allusions to the princes or people by whom they were minted.

I am, my dear Sir,

Very faithfully yours,

\section{J. Y. AKERMAN.}

William J. Thoms, Esq. F.S.A.

\&c. \&c. \&c.

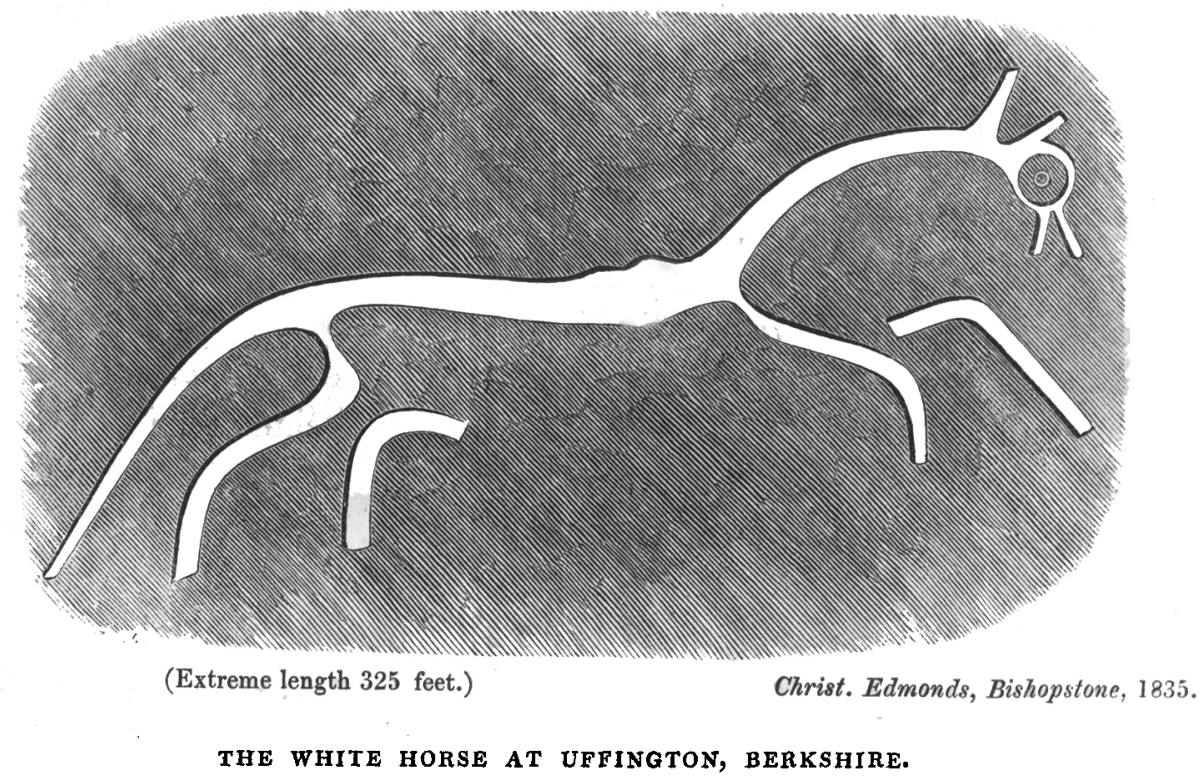

